\title{
Sufisme IN JAVA: \\ The Meeting Point between Sufism and \\ JAVANESE MYSTICISM
}

\author{
Ach. Nashichuddin \\ Dosen Fakultas Saintek Universitas Islam Negeri (UIN) Malang
}

\begin{abstract}
Wali Songo adalah paguyupan ulama yang bukan hanya penyebar agama Islam tetapi juga sebagai pembawa ajaran tasawuf di pulau Jawa. Dilihat dari ajarannya, mereka adalah penganut aliran tasawuf sunni yang banyak mengadopsi ajaran-ajaran imam Al-Ghazali. Dalam mengembangkan ajarannya mereka mendirikan lembaga pendidikan yang disebut pesantren, yaitu lembaga pendidikan yang sekaligus menyediạkan asrama sebagai tempat tinggal bagi para santri. Dalam menyebarkan agama Islam mereka dengan mudah diterima oleh masyarakat Jawa. Hal ini tidak terlepas dari ajaran-ajaran yang mereka kembangkan, ajaran-ajaran tasawuf, ada kesamaan dengan ajaran mistik yang dianut masyarakat Jawạ.
\end{abstract}

Keywords: tasawuf, mistik

\section{A. Introduction}

Sufism first came to Indonesia along with the spread of Islam brought to the region by Moslem traders. There is still controversy among scholars about who first brought Islam to Indonesia. Some point to Moslem traders from Persia and Gujarat, others offer evidences of Arab (either from Egypt, Hejaz, or Hadramaut) influences on early Indonesian Moslems. (www. geocities.com) Another point is mentioned by A. H. Johns, an Australian philologist. He said that Islam was brought to Indonesia by Moslem traders who were members of a Sufi order from Baghdad after Mongolians attacked it around 1258. (Abdullah;1994) However, everyone agrees that Islam entered Indonesia peacefully without holy wars or rebellions. That is perhaps because Sufism played a big role in spreading Islam among Indonesians who were and still are very fond of mysticism. 
Islam was also spread in Java by Sufi masters who were known as Wali Songo (nine Sufi saints). Wali Songo was actually a council of Sufi masters that was first formed by Sunan Ampel (Raden Rahmat) around 1474 which always consisted of nine members. If one of member died or move abroad, he would be replaced with a new one, elected by the remaining members. The first council consisted of:

1. Raden Rahmat (Sunan Ampel) led the council and resided in Ampel Surabaya East Java.

2. Raden Hasan was placed in Bintara, Demak with the title Pangerang (prince) Bintara. Also he was known as raden Fatah, the first king of Demak Sultanate.

3. Raden Makdum Ibrahim stayed in Daha with the title Pangeran Anyakrawati. He was the first son of Sunan Ampel and later was known as Sunan Bonang.

4. Raden Qosim or Raden Alim resided in Majagung with the title Pangeran Majagung. He was the second son of Sunan Ampel and later was known as Sunan Drajad.

5. Usman Haji stayed in Ngudung and had the title of Pangeran Ngudung.

6. Raden Ainul Yakin or Raden Paku resided in Giri (near Gresik). He had the of title Pangeran Giri and later was known as Sunan Giri.

7. Sheikh Abdul Jalil stayed in Lemah Abang. He had title of Sheikh Lemah Abang and later was known as Sheikh Siti Jenar.

8. Raden Hamzah was placed in Singasari. He had the title of Pangeran Tumapel.

9. Raden Mahmud built a base in Drajad, near Tuban. (www.geocities.com)

The council was intended to support Islamic propagation in Java. Therefore, it planned particular approaches and methods in its movement, for instance, a political approach of building a group of missionaries was called Bayangkare Ishlah and a cultural approach of entering Islamic teaching into Javanese culture.

The second wave of Sufi movement in Indonesia, especially in Java, was when the Sufi orders entered around the nineteenth century. It was 
brought by Indonesian Moslems who went to Mecca and Medina for hajj or pilgrimage. The famous order in the archipelago was the QodiriyyahNaqshabandiyyah order that supported by Sheikh Ahmad Khatib Sambas, one famous 'ulama' of Indonesian birth (Zulkifli;2002). In this paper, I shall limit my discussion to just two parts, the first about Sufism in the Wali Songo era and the second one about the meeting point between Sufism and Javanese mysticism.

\section{B. Sufism in the Wali Songo Era}

In the sixteenth century there are two important points to be explored. The first is the concept of Sufism that was established among the Indonesian Moslems, for instance, the orthodox concept that tended to transcend the concept of Al-Gozali-and the unorthodox concept that tended toward the pantheist concept of Ibnu Araby (in Javanese, called manunggaling kaurulo Gusti). In Java, those concepts seem to contradict each other. The orthodox concept appeared mostly in pesantren, the traditional Islamic educational institutions in Java. This means that the concept was taught to students in pesantren. In contrast, the unorthodox concept was not taught in pesantren, butit still developed fully in Javanese literatures and documents. It was not taught to students, but instead was written by few members of the Wali Songo in Javanese literatures and documents. This was different from the establishment of Sufism in Aceh, Both concepts could sit together in the pesantren circle (Simuh;1999). The second important point is the assimilation of Islamic teaching and Javanese culture and literature. This is one of approaches used by Wali Songo to make Islam accepted by Javanese people.

In that era, pesantren had a large role in the maintenance of Sufism, especially in Java. Most of the member of Wali Songo used pesantren, at least a mosque ${ }^{2}$, to be a center for da'wah and education. Some scholars even believe that Wali Songo was the founding father of pesantren. That is said by Hajj Abu Bakar Atjeh that Sheikh Mawlana Malik Ibrahim, known as Sheikh Maghribi, from Gujarat, India is regarded as the founder of the first pesantren. The pesantren produced Moslem preachers who spread the Holy religion throughout Java (Zulkifli; 2002). Sunan Ampel also used pesantren 
as a center of his da'wah. When he was given authority over Ampel region by his uncle, Sri Kertawijaya, king of Majapahit, he built a pesantren there. Moslem children studied Islam there, and he hoped for them to become future missionaries for the archipelago. In a short time, Ampel grew to be a center for studying Islam on the island and hosted religious scholars from various countries. (www.goecities.com) Moreover, an interesting one is that Sufism was the basis of Sunan Ampel's teaching. In addition, Ghazalian Sufism is more dominating than Ibn Arabian Sufism among the member of Wali Songo. This can be proven from a Javanese manuscript called Nasihat Syekh Bari (The Admonitions of Sheikh Bari) written by Sunan Bonang, a member of Wali Songo. He clearly quoted Ghazali's thoughts. He writes:

Imam Ghazali said: sheikh Sufi (a proper name)! You are infidel according to the four schools, because your doctrines detract from the attributes of the Lord. Because you attribute non-existence to or minimize the attribute of the Lord your words have been branded as heretical. You will have it that they are to be interpreted as a mystic utterance, but the mystic would not speak in this vein. For/with the mystic it is as expressed in the words: la ya'rifu 'abdiyatahu la yanzuruha la yadhkuruha (he does not know of his servant ship, does not see it or have remembrance of it), i.e. The mystic is unconscious of his own being, oblivious of his own speech and sight and has no knowledge of the Lord (as a separate being). This is the meaning of the words; realized, overpowered, replaced, blotted out as regards existence, speech and sight, as it is only the mercy and the grace of the Lord that one is granted annihilation. That is what the mystic is like, and not what you said, detracting from the attributes of the Lord because you are tainted by the heresy of the Mu'tazilah (Amin;2002).

As mentioned above, the Sufism thought of Wali Songo entered easily to Javanese literatures and culture and even was regarded as Islamizing of Javanese literatures. This happened because of many factors, the first, according to A.H.Johns, is that there was a similarity between Wali Songo's teachings that tended to Sufism and Javanese culture that tended to mystical matters. Therefore, da'wah of Wali Songo could be accepted easily by Javanese people (Simuh;1999). The second is the Islamizing of culture and literature is not only supported by Moslem missionaries, but it is also 
supported the rulers and administrators who have the task of carrying out the duties of the Javanese culture. This happened clearly in the era of the Mataram kingdom. Sultan Agung, the king of Mataram, pioneered the process of Islamizing. He asked the ulama' to be involved and to take a role in his government. He also succeeded in changing the Saka year calculation (Javanese calendar) to become the Hijriyah year calculation. This means that after the change, Javanese people still use the Saka year but it was accounted by Hijriyah calculation. Some men of letters in the kingdom circle also follow the effort. They tried to rewrite and change some ancient Javanese literatures that were not understood by Javanese people into the new Javanese language so the common people could understand it and be adapted with the Islamic era. This means that they united Javanese literatures with the Islamic teaching and created a new literature called Islam Kejawen (Islamic-Javanese) literature. For example, they Islamized serat Bimasuci (Bimasuci writing). This writing consisted of the core of notions and philosophies of Javanese mysticism, as said by DR. Soewito Santoso. He writes:

We see a Javanese Moslem interpreting the Bimasuci in the Islamic manner or in other words making the Bimasuci acceptable to Moslem. Yet it can be seen in another light, namely that he tries to make Islam accepted by people who still believe in the mysticism of the Bimasuci. So we can understand the case on one hand as an attempt to Islamize the Bimasuci, and the other hand to localize Islam (Simuh;1999).

In short, we see here that the process of Islamizing of Javanese culture and literature has two functions. The first is to introduce aspects of Islamic teaching to Javanese people and to lovers of Javanese literatures. The second is that the process is due to Javanese literatures becoming acceptable to Moslem community.

\section{The Meeting Point of Sufism and Javanese Mysticism}

The term of Sufism here refers to the orthodox concept that tends toward Ghazaian Sufism. That's because most members of Wali Songo were Sufis in the orthodox Ghazalian mold. Therefore, the core of their teaching is achieving Insan Kamil (perfect man) quality. The process has to begin 
from syariah, Thariqah, Hakekat, and the highest level is Ma'rifah (Murtadho; 2002). This means that mysticism has to begin from physical worship in the frame of religious teaching before achieving the highest level, Ma'rifah.

Javanese mysticism is actually the representation of the way of philosophical thinking of Javanese people. Therefore, from Javanese mysticism we can know how Javanese people think about life, a person, the world and God. This means that Javanese mysticism consists of spiritual experiences seeking the meaning of life in the world, the origin of life, the goal of life, and the relationship between humans and God. That's actually the Javanese philosophy of life, namely the attitude of life for seeking perfection of life through ngelmu sangkan paraning dumadi (understanding the origin and the goal of life) and manunggaling kawula Gusti -unity with God(Endraswara; 2003).

Instruction and messages about sangkan paraning dumadi (the origin and the goal of life) are still held firmly by the followers of Javanese mysticism. Sunan Kalijaga has instructed as in the dhandhanggula poetry below;

Urip iku neng donya tan lami,

Upamane jebeng menyang pasar,

Tan langgeng neng pasar bae,

Tan wurung nuli mantuk,

Mri wismane sangkane nguni,

Ing mengko aja samara, sangkan paranipun,

Ing mengko padha weruha,

Yen asale sangkan paran duk ing nguni,

Aja nganti kesasar.

The mystical message of the poetry is that life in the world is not long; it's like a person who goes to market, and will come back home to his origin soon, therefore, don't doubt your origins, and don't go the wrong way. The message instructs that human being lives in the world just briefly, and soon he will be back to God. God is the pillar of "sangkan paraning dumadi" (the origin and the goal of life). (Endraswara; 2003)

The second way to seek the perfection in life is through "manunggaling kawula-Gusti" (unity of human being with God). According to Javanese mystical teachings, the key word in the statement is "kawula-Gusti" (human 
being and God). Human being has to come closer to God, and eventually he will achieve the highest degree, namely unity with God. In Suluk Saloka Jiwa, R. Ranggawarsita explains that God is like sesotya (jewel) and human being is like embanan (bowl). The unity of God to human being is like a jewel in a bowl. God is immanent in the body of human being, but also covers the human being. Moreover, nature, human being, and God is one and similar (Endraswara;2003).

Manunggaling kawula-Gusti can be achieved through concentration, restraint passions, releasing the inner from the sensorial world (pemudhara), understanding real knowledge and knowing the essence of life. As mentioned in the serat Chenthini $\mathrm{V}$, real knowledge can be done through mystical action called mati raga (dead of body). A human being who can act mati raga (dead of body) devoutly, will become makal, who can unity with God because the origin and the essence of human being is similar with God (Endraswara;2003). Thus, what are the meeting points between Sufism and Javanese Mysticism?

Basically, Sufism and Javanese Mysticism have clear meeting points in the goals of their actions. Both bring the follower close to God. If Sufism uses meditation for concentration, Javanese mysticism also uses meditation or spiritual consciousness that free them from intervention of the mind and senses for seeking knowledge about the essence of God. In this point, the main goal of Sufism or mysticism is achieving the highest level of ma'rifat.(Endraswara;2003)

In addition, Mark Woorward, as quoted by Murtadho, concludes that essentially between Islam, including Sufism, and Javanese mysticism have similarities and meeting points at least in their four concepts. ${ }^{3}$ The first is the concept about the oneness of God. In Islam, oneness of God concept is the essence and the main doctrine called tauhid. Javanese mysticism also has the concept of the oneness of God. This can be seen from the goal of its belief, namely concern and unity with God.

Another similarity is the concept of internal and external meaning. In Islam, especially in Sufism, mentioned that the external meaning of the Koran is to organize behavior, and the internal meaning is mystical matters and knowledge about God. In Javanese tradition, internal and external 
terms are mentioned in other words, namely the wadah (bowl) and isi (content). The bowl is intended for visible matters, for instance, real thing, the body of human being and so on, and content is intended for substantive matters, namely God, soul, belief, and mysticism.

Third similarity is the concept about the relationship between creatures and God. In Sufism we find many concepts that mention the relationship between creatures and God, for example, Ittihad, al Hulul, and Wahdah al Wujud. In Javanese mysticism we also find discussion about relationship between creature and God as Jumbuhing Kaurlo Gusti and Manunggaling Kawulo Gusti.

The fourth similarity is the concept of micro cosmos and macro cosmos. In Sufism we find the concept of human beings as the imagination of God, human being as micro cosmos and God as macro cosmos. In Javanese mysticism we find a similar concept with micro cosmos and macro cosmos, namely the concept of the Ka'bah and heart. The Ka'bah as the center of macro cosmos is similar with the heart as micro cosmos. Based on this concept, in Javanese perception there is opinion says that hajj or pilgrimage is not to be in Mecca, but it is enough to have the feeling in the heart.

\section{Conclusion}

The meeting point between Sufism and Javanese mysticism is the main factor in the success of Wali Songo's mission in Java. Moreover, it can produce a new style of religious sect called Javanese Islam. Javanese Islam is the combination between Islamic teaching and Javanese culture and tradition that I mentioned above as Islamizing of Javanese culture and tradition. However, Indonesian modernists Moslems refuse the tradition as heresy.

In my opinion, Javanese Islam is Islamic tradition with Javanese characteristics. Islam came to Indonesia in two ways, Islamic teaching and Islamic tradition shaped by Arabic tradition. Of course, Arabic tradition is different from Javanese tradition. Therefore in this case, Javanese Islam is possible to develop its own characteristics, Islam with Javanese tradition. 


\section{Daftar Pustaka}

Dudung Abdullah, "Sufi dan Penguasa, Perilaku Politik Kaum Tarekat di Priangan Abad XIX-XX" (Sufism and the Ruler, Political behavior of Sufi Order in Priangan on 19-20 century), Al-Jamiah, No. 55, 1994.

M.Darori Amin (edit), "Islam dan Kebudayaan Jawa", (Islam and Javanese Culture), Jogjakarta, GAMA MEDIA, 2002

M. Murtadho, "Islam Jawa, Keluar dari kemelut Santri versus Abangan" (Islam Java, exit from crisis of Santri and Abangan), Yogyakarta, LAPERA, 2002.

Simuh, "Sufisme Jawa, Transformasi Tasaunf Islam ke Mistik Jawa" (Javanese Sufism, a Transformation of Islamic Mysticism into Javanese Mysticism), Yogyakarta, Yayasan Bentang Budaya, 1999.

Suwardi Endraswara, "Mistik Kejawen". (Javanese Mysticism), Yogyakarta, NARASI, 2003.

www.geocities.com, History of Sufism in Indonesia, www.geocities.com, Walisongo, the Nine Sufi Saints of Java.

Zulkifli, "Sufism in Java, The Role of the Pesantren in the Maintenance of Sufism in Java", INIS, Leiden-Jakarta 2002. 